\title{
Flowering and fruiting seasonal changes of six accessions of Jatropha curcas L. in a semi-arid region of Senegal
}

\author{
Ibrahima Diedhiou ${ }^{1} \bowtie$, Roger Bayala ${ }^{1}$ Moustapha Diere Sagna ${ }^{1}$ \\ and Diedhiou Pape Madiallacke ${ }^{2}$
}

\author{
${ }^{1}$ Ecole Nationale Supérieure d'Agriculture (ENSA), Université de Thiès (UT), \\ BP A 296, Route de Khombole, Thiès, Sénégal \\ 2UFR des Sciences Agronomiques d'Aquaculture et de Technologies Alimentaires (UFR S2ATA)/ \\ Université Gaston Berger de Saint-Louis (UGB), Route de Ngallèle BP 234 Saint-Louis, Sénégal \\ idiedhiou@univ-thies.sn
}

\begin{abstract}
Jatropha curcas is the priority species for biofuel promotion in Senegal. However the lack of knowledge on floral biology and fruiting of this plant remains a problem to increase its yield and impr ove farmers' adoption. The objectives of this study were to assess seasonal changes on flowering and fruiting of six accessions of Jatropha curcas in semi-arid area, Senegal. In this study the total number of inflorescences, flowers and fruits were evaluated during six months on four years old plants, installed in the Agricultural Engineering School ( ENSA) of Thies. The results showed significant effect of the studied factors (season, accession) and interaction between them on floral and fruiting traits of $J$. curcas. Due to more favorable climatic conditions, the performance of flowering is better in the wet season. During this season, the number of male and female flowers ranged, respectively from 107.47-191.60 and from 2.47-11.87 per inflorescence. Consequently, ripe fruits production was higher in wet season and varied between 66 and $97 \%$ of the total production. Two peaks of flowering were observed; the first one occurred in dry season (April, 24th- June 6th) and the second, with the highest number of inflorescences, arrived in wet season ( 8 - 22 July). Fruiting patterns is highest concentration between at the end of the wet season (September 15th and October 3rd). High seed yieldswere observed withthe accessions CE6 (2739.3 kg ha-1), CE97 (1451.0 kg ha-1) and CE95 (1326.3 kg ha-1) that are promising for biofuel production in semi-arid areas of Senegal.
\end{abstract}

Keywords: climate,Jatropha curcas, phenology, Senegal, yield

\section{INTRODUCTION}

Jatropha curcas $\mathrm{L}$. is a perennial species belonging to the Euphorbiaceae family and nativeof Mexico and Central America (Heller, 1996). It was introduced in Africa in the 16th century via the Cape Verde Islands. Nowadays, it iswidelycultivated in Asia, Africa and America for its various products and benefits which can support an integrated rural development. The oil extracted from seeds has high-energy value whose properties are similar to diesel oil (Heller, 1996). It is also used for soap or lubricants manufacturing and the seed cakes as manure (Traoré et al., 2015). 
However, many studies have reported that the lower yield of this species is one of the major constraintsto its integration into agricultural production systems (Wijaya et al., 2009; Diédhiou et al., 2012; Everson et al., 2013). Under these conditions improvement of J. curcas yield becomes imperative to enhance profitability of the plantations. To realize this perspective, it is necessary to have reliable data on flowering, fruiting and relationship between them. Indeed, these data are essential to develop and plan strategies selection and breeding (Kaur et al., 2011).

In wet regions of Asia such as India, Malaysia and Indonesia, many studies focused on $\mathrm{J}$. curcas phenology characteristics and especially its floral biology. These aspects have so far received little attention in North America, where it is noted exceptionally, the study of Nietzsche et al. (2014) carried out in south Florida. It emerged from these investigations that $J$. curcas is a monoecious and diclinous (with inflorescences of unisexual flowers) species. However, sometimes J. curcas might also produce hermaphrodite flowers (Fresnedo-Ramirez, 2013). Flowering begins in first year if environmental conditions are favorable (Silip et al., 2010). However, flowering is more important in the second and third years after plantation. The flowering cycle of $J$. curcas can happen the whole year in wet areas (Vidal, 1962). It is noticed that plants from cuttings get flower earlier that those from seeds.

The number of flowering peaks depends on moisture and nutrients availability. Flowering characteristics are significantly affected by the season (Nietzsche et al., 2014) and accessions origin (Wijaya et al., 2009; Nietzsche et al., 2014). The inflorescence of J. curcas is a raceme (Kaur et al., 2011). It carries more male flowers (from 25-215) than female flowers (from 0-16.6) (Raju \& Ezradanam, 2002; Ghosh \& Singh, 2008; Wijaya et al., 2009; Alam et al., 2011; Kaur et al., 2011; Nietzsch et al., 2014; Mat et al., 2015). The male to female flower ratio is an important factor because it is significantly correlated to yield (Wijaya et al., 2009). It is between 7.14 and 55.4 (Raju \& Ezradanam 2002; Ghosh \& Singh, 2008; Rao et al., 2008; Wijaya et al., 2009; Alam et al., 2011; Kaur et al., 2011; Nietzsche et al., 2014). The morphological characteristics of flowers of J. curcas (color, number of petals and sepals, size, number of stamens, features of pistil), have been described by Alam et al. (2011). Pollination of J. curcas is mainly provided by insects especially bees, butterflies, flies, dragonflies, beetles and ants (Ghosh \& Singh, 2008; Kaur et al., 2011). It is usually cross-pollinated types, but the case of pollination between flowers of the same plant happens.

Fruiting of $J$. curcas can starts in the first year. According to Silip et al. (2010), flowering tofruit set occurs within one to eight days. Fruits develop physiologically or reach mature green stage within 21 to 35 days. The species can have until four cyclical fruiting peaks per year (Alam et al., 2011). Fruitto female flower ratio (fruit set) varies from 0.37 to 0.79 (Gosh \& Singh, 2008; Kaur et al., 2011; Nietzsche et al., 2014). The yield of J. curcas has wide variation (from 32 to $745.72 \mathrm{~g} /$ tree) according to origin, age, soil, climate and farming practices (Heller, 1996; Rao et al., 2008; Wijaya et al., 2009; Wani et al., 2012; Diédhiou et al., 2012; Shabanimofrad et al., 2013; Singh et al., 2013). Although J. curcas is considered tolerant to drought, several studies (Kaur et al., 2011; Ma et al., 2016) showed that water 
has a significant effect on its phenology and particularly fruiting.

If $J$. curcas phenology seems to be well documented in Asia, while in west Africa and especially in the Sudano-Sahelian areas where climate and soil conditions are different, there is little information on this question (Ahoton \& Quénum, 2012).

In these conditions, the objective of this study was to analyze seasonal changes in flowering and fruiting of six $J$. curcas accessions in a semi-arid region of Senegal.

\section{MATERIAL AND METHODS}

\section{Study site}

The experiment was carried out in research station of National School of Agriculture (ENSA), located at $4 \mathrm{~km}$ away from Thiès (14'42'52' $\mathrm{N}$ and $\left.16^{\circ} 28^{\prime} 64^{\prime \prime} \mathrm{W}\right)$, in Senegal. The climate is tropical semi-arid with short rainy season (June to October) and long dry season (November to May). The total annual precipitation is $480 \mathrm{~mm}$ (Kizito et al., 2006). During the experiment, the rain was collected with Decagon weather station (Decagon Devices, Inc., Pullman, WA, USA). The rainfall started in the third 10 days of June and become more and more important from July. August and September were wetted months with respectively, 233.6 and $226.8 \mathrm{~mm}$ cumulative rainfall. The quantity of precipitation of these months represents $81 \%$ of the total annual rainfall $(568.2 \mathrm{~mm})$. Overall, there was a good distribution of precipitation during that year.The mean annual minimum ambient temperature is $19^{\circ} \mathrm{C}$ and a mean annual maximum ambient temperature of $33^{\circ} \mathrm{C}$. The minimum and maximum of relative humidity range from 49 to $91 \%$ in rainy season and from 27 to $75 \%$ in dry season. The study site lies on a leached and disturbed ferruginous sand soil classified as a ferruginous Oxisol (FAO, 1998). The top horizon $(0-0.7 \mathrm{~m})$, is sandy with a friable continuous structure and no distinct horizonation with low clay content of about $5 \%$. The organic matter and nitrogen content is about 0.5 and $0.3 \%$ respectively and water-retention capacity ranging from 60 to $100 \mathrm{~mm}$ (Zanté, 1983).

\section{Experimental design}

A set of six accessions of $J$. curcas, where four were from Senegal, one from Tanzania and one from Mozambic was used for the experiment. Accessions codes in ENSA's collection and the rainfall of their ecological areas are shown in table 1. Seedlings of the six accessions were produced from vigorous seeds in a nursery using polybag containing a mixture of soil and compost in the ratio of $1: 1$. Four months old seedlings were established in the field during August 2008. Seedlings were irrigated during 90 days after planting and at 15 days intervals. No fertilization and pruning have been done. Weeding was performed as needed, usually in rainy season. The experimental design is a randomized block design (RBD) with six treatments (accessions) and four replicates. The sub-plot was a square of $6 \mathrm{~m}$ side and had 16 trees. Planting spacing was $2 \mathrm{~m}$ in-row $\times 2 \mathrm{~m}$ between-rows, having 2500 plants per hectare.

At the time of the study, trees were 42 months old. All accessions had started flowering at the second year after plantation. 
TABLE 1. Accessions of $J$. curcas and ecological characteristics of their origin.

\begin{tabular}{|l|l|l|l|l|}
\hline \multicolumn{1}{|c|}{ Accession } & Code & Rainfall $(\mathbf{m m})$ & Ecological zone & Country of collection \\
\hline Plantation 1 & CE6 & 400 & Sahelian & Senegal \\
\hline Noto 3 & CE14 & 400 & Sahelian & Senegal \\
\hline Keur Samba Gueye & CE50 & 800 & Sudanian & Senegal \\
\hline Ngodiba & CE95 & 800 & Sudanian & Senegal \\
\hline Tanzanie & CE97 & N/A & N/A & Tanzania \\
\hline Mozambique & CE98 & N/A & N/A & Mozambique \\
\hline
\end{tabular}

(N/A): Not Available

\section{Sampling and data collection}

Flowering phenology

The flowering survey was carried out during nine months (February- October 2012) on three trees per accession, randomly selected in three blocks of the experimental plot.

Quantitative flowering traits were recorded, including the total number of inflorescences per tree, the number of female flowers per inflorescence, the number of male flowers per inflorescence and the male to female flower ratio.

The total number of inflorescences per tree was counted every 14 and 7 days respectively in dry season and rainy season.

The flowers sex parameters were recorded by simple count method once in May (dry season) and September (wet season). In the wet season, this survey was carried out on the six accessions; but in the dry season it was conducted on only four accessions (CE6, CE95, CE6 and CE97) which produced recognizable flowers in this season. Fifteen inflorescences per each of the three selected trees per accession were sampled, so a total of 45 inflorescences were considered per accession.

\section{Fruiting phenology}

The fruiting survey was performed during 10 months (February- November 2012) on four trees per accession, randomly selected in four blocks of the experimental plot. Observations were made every 14 and seven days respectively in dry season and rainy season.

The yield (seed weight per hectare for the density of 2500 plants/ha) and its components (number of fruit per tree, fruit weight per tree, fruit weight and seed weight per tree) were calculated for each season and also for the whole duration of the survey.

The number of fruitwas recorded by simple count method. The fruit weight and the seed weight weremeasured by electronic balance in the laboratory.

\section{Data analysis}

The data were submitted to a two waysanalysis of variance (ANOVA) using STATISTIX. Means separation among treatments was performed by Tukey's test at the $5 \%$ probability level based on the F-test of ANOVA. 


\section{RESULTS AND DISCUSSION}

\section{Flowering phenology}

The flowering rhythms of the six J. curcas accessions are summarized in fig. 1. All accessions produced inflorescences continuously throughout the observation period. However, the full flowering occurred between April (dry warm season) and July (early in rainy season) for all accessions. Accessions had two peaks of flowering. The first peak occurred in dry season (April, 24th - June 6th) and the second, with the highest number of inflorescences, arrived in wet season (8 - 22 July).

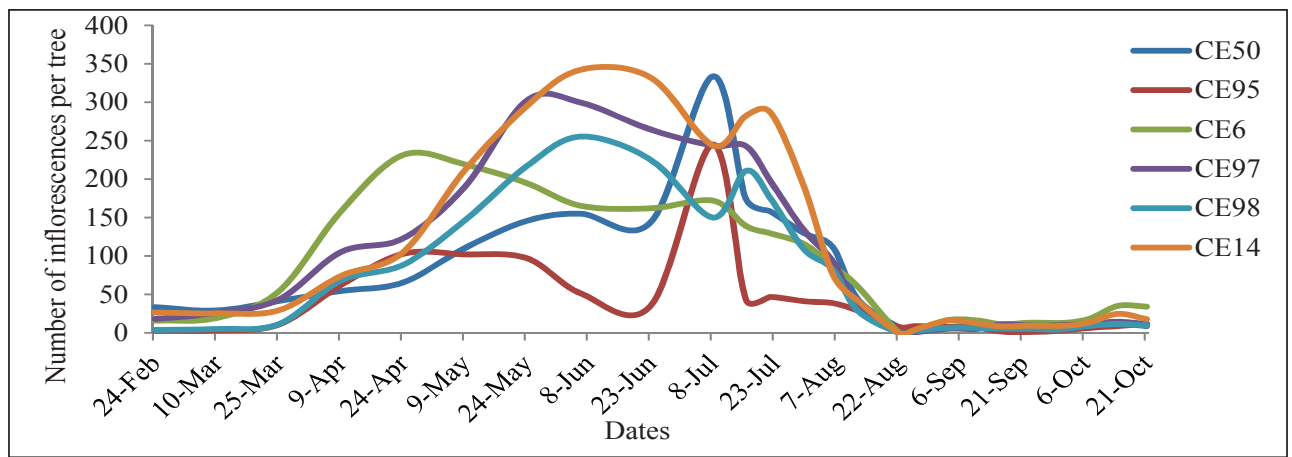

FIG. 1. Number of inflorescences per tree according to the time for six J. curcas accessions.

The effect of the season on number of male flowers per inflorescence, number of female flowers per inflorescence and male to female flower ratio is shown in table 2.There were significant differences between seasons $(p<0.05)$ for the number of female flowers per inflorescence but not forthe number of male flowers per inflorescence. The number of female flowers per inflorescence was significantly higher in the wet season than in the dry season. Consequently, the male to female flowers ratio was lower in the wet season compared to the dry season.

TABLE 2. Effect of the season on flowering parameters of J. curcas.

\begin{tabular}{|l|l|l|l|l|}
\hline \multirow{2}{*}{\multicolumn{2}{|c|}{ Parameters }} & \multicolumn{2}{c|}{ Seasons } & \multicolumn{2}{c|}{ Statisticalparameters } \\
\cline { 2 - 6 } & \multicolumn{1}{|c|}{$\begin{array}{c}\text { Dry } \\
\text { season }\end{array}$} & $\begin{array}{c}\text { Wet } \\
\text { season }\end{array}$ & \multicolumn{1}{|c|}{ F } & \multicolumn{1}{|c|}{ P } \\
\hline Number of male flowers per inflorescence & $143.76 \mathrm{a}$ & $138.38 \mathrm{a}$ & 0.58 & 0.448 \\
\hline Number of female flowers per inflorescence & $4.28 \mathrm{~b}$ & $6.84 \mathrm{a}$ & 13.91 & $<0.001$ \\
\hline Male to female flower ratio & 33.59 & 20.23 & - & - \\
\hline
\end{tabular}

(-): no analysis of variance; means followed by the same letter within columns do not differ significantly at $\mathrm{P}<0.05$ by Tukey's test.

The influence of the accession on number of male flowers per inflorescence, number of female flowers per inflorescenceand male to female flower ratio is presented in table 3.There were significant differences between accessions $(p<0.05)$ for all flowering parameters. Number of male 
flowers per inflorescence ranged from 127.10 to 149.88 and the number of female flowers per inflorescence ranged between 3.68 and 6.88 . These parameters were significantly higher for the accessions CE6 and CE97; consequently the ratio values of these accessions were the lowest.

TABLE 3. Influence of the accession on flowering parameters of $J$. curcas.

\begin{tabular}{|l|c|c|c|c|c|c|}
\hline \multirow{2}{*}{ Parameters } & \multicolumn{4}{|c|}{ Accessions } & \multicolumn{2}{c|}{ Statistical parameters } \\
\cline { 2 - 7 } & CE50 & CE95 & CE6 & CE97 & F & P \\
\hline $\begin{array}{l}\text { Number of male flowers } \\
\text { per inflorescence }\end{array}$ & $130.30 \mathrm{~b}$ & $127.10 \mathrm{~b}$ & $157.00 \mathrm{a}$ & $149.88 \mathrm{ab}$ & 4.33 & 0.007 \\
\hline $\begin{array}{l}\text { Number of female } \\
\text { flowers per inflorescence }\end{array}$ & $3.68 \mathrm{~b}$ & $5.21 \mathrm{ab}$ & $6.48 \mathrm{a}$ & $6.88 \mathrm{a}$ & 4.40 & 0.006 \\
\hline $\begin{array}{l}\text { Male to female flower } \\
\text { ratio }\end{array}$ & 35.41 & 24.40 & 24.23 & 21.78 & - & - \\
\hline
\end{tabular}

(-): no analysis of variance; means followed by the same letter within columns do not differ significantly at $\mathrm{P}<0.05$ by Tukey's test.

The influence of the interaction between accession and season on flowering parameters is summarized in table 4 . The datashowed a significant effect $(p<0.05)$ on all flowering parameters. The number of male flowers per inflorescence varied from 103.77 to 187.90 . Maximum value of this parameter was observed for CE6 during wet season, followed by CE50 and CE97 during dry season.

TABLE 4. Interaction effect of accession and season on flowering parameters of $J$. curcas.

\begin{tabular}{|c|c|c|c|c|c|c|c|c|c|c|}
\hline \multirow{3}{*}{ Variables } & \multicolumn{8}{|c|}{ Accessions $\mathrm{x}$ saisons } & \multicolumn{2}{|c|}{$\begin{array}{l}\text { Statistical } \\
\text { parameters }\end{array}$} \\
\hline & CE50 & & CE95 & & CE6 & & CE97 & & $F$ & $\mathbf{P}$ \\
\hline & $\begin{array}{c}\text { Dry } \\
\text { season }\end{array}$ & $\begin{array}{c}\text { Wet } \\
\text { season }\end{array}$ & $\begin{array}{c}\text { Dry } \\
\text { season }\end{array}$ & $\begin{array}{c}\text { Wet } \\
\text { season }\end{array}$ & $\begin{array}{c}\text { Dry } \\
\text { season }\end{array}$ & $\begin{array}{c}\text { Wet } \\
\text { season }\end{array}$ & $\begin{array}{c}\text { Dry } \\
\text { season }\end{array}$ & $\begin{array}{c}\text { Wet } \\
\text { season }\end{array}$ & & \\
\hline $\begin{array}{l}\text { Number of male flowers } \\
\text { per inflorescence }\end{array}$ & $156.83 a b$ & $103.77 \mathrm{c}$ & $138.83 b c$ & $115.37 \mathrm{bc}$ & $126.10 b c$ & 187.90a & $153.27 a b$ & $146.50 \mathrm{abc}$ & 12.05 & $<0.001$ \\
\hline $\begin{array}{l}\text { Number of female } \\
\text { flowers per inflorescence }\end{array}$ & $5.18 b c$ & $2.18 \mathrm{c}$ & $5.11 b c$ & $5.31 \mathrm{bc}$ & $1.38 \mathrm{c}$ & $11.58 \mathrm{a}$ & $5.45 b c$ & 8.31ab & 16.71 & $<0.001$ \\
\hline $\begin{array}{l}\text { Male to female flower } \\
\text { ratio }\end{array}$ & 30.28 & 47.60 & 27.17 & 21.73 & 91.38 & 16.23 & 28.12 & 17.63 & - & - \\
\hline
\end{tabular}

(-): no analysis of variance; means followed by the same letter within columns do not differ significantly at $\mathrm{P}<0.05$ by Tukey's test.

The number of female flowers per inflorescence ranged from 2.18 to 11.58. Highest valueswere recorded for CE6 during wet season, followed by CE97 during wet season. The range for male to female flower ratio varied from 16.23 to 91.38. Lowest values were observed for CE6 during wet season, followed by CE97 wet season and CE95 wet season.

The flowering characteristics of the six accessions in the wet season are presented in table 5 . All accessions produced flowers. The analysis of variance revealed that CE6 had a higher 
number of male flowers (187.90) compared to the other accessions (table 5). The accession CE50 showed the lowest value of this character (103.77). For the number of female flowers per inflorescence, the highest was seen in CE6 (11.58) while the lowest in CE50 (2.18). The accessions CE97 and CE98 had intermediate values for this parameter, 8.31 and 6.98 respectively. Male to female flowers ratio recorded was highest for CE6 (16.23) and lowest for CE50 (47.60).

TABLE 5. Influence of the accession on flowering parameters of $J$. curcas during wet season.

\begin{tabular}{|l|c|c|l|l|l|l|l|l|}
\hline \multirow{2}{*}{ Parameters } & \multicolumn{3}{|l}{ Accessions } & \multicolumn{2}{l|}{$\begin{array}{l}\text { Statistical } \\
\text { parameters }\end{array}$} \\
\cline { 2 - 10 } & CE50 & CE95 & CE6 & CE97 & CE98 & CE14 & F & P \\
\hline $\begin{array}{l}\text { Number of male flowers } \\
\text { per inflorescence }\end{array}$ & $103.7^{\mathrm{c}}$ & $115.37^{\mathrm{bc}}$ & $187.90^{\mathrm{a}}$ & $146.50^{\mathrm{b}}$ & $137.77^{\mathrm{bc}}$ & $122.03^{\mathrm{bc}}$ & 9.64 & $<0.001$ \\
\hline $\begin{array}{l}\text { Number of female } \\
\text { flowers per } \\
\text { inflorescence }\end{array}$ & $2.18^{\mathrm{c}}$ & $5.31^{\mathrm{bc}}$ & $11.58^{\mathrm{a}}$ & $8.31^{\mathrm{ab}}$ & $6.98^{\mathrm{b}}$ & $4.98^{\mathrm{bc}}$ & 11.17 & $<0.001$ \\
\hline $\begin{array}{l}\text { Male to female flower } \\
\text { ratio }\end{array}$ & 47.60 & 21.73 & 16.23 & 17.63 & 19.74 & 24.50 & - & - \\
\hline
\end{tabular}

(-): no analysis of variance; means followed by the same letter within columns do not differ significantly at $\mathrm{P}<0.05$ by Tukey's test.

\section{Fruiting phenology}

The fig. 2 summarizes the fruits production of accessions from February to November. All accessions showed continuous fruit production during the experiment survey and average fruits production patterns were fairly similar for all accessions. Fruiting patterns is highest concentration between September 15th and October 3rd.

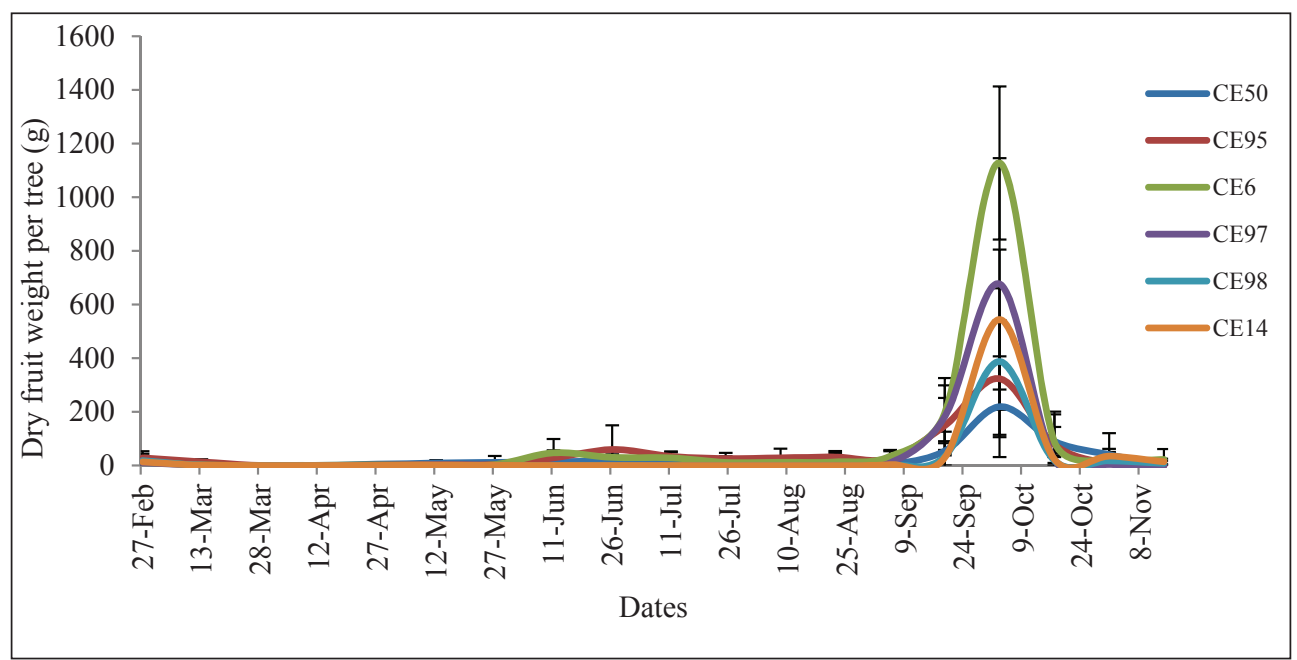

FIG. 2. Dry fruit weight per tree according to the time for six J. curcas accessions. 
During dry (end of April) CE50, CE95 and CE6 had low fruit production while CE97, CE98 and CE14 had nearly no production. In full production period, CE95 and CE97 produced $66 \%$ and $97 \%$ of total production respectively. For EC50, EC6, CE98 and CE14, average was $73 \%$, $87 \%, 94 \%$ and $95 \%$ of total fruit production.

The effect of the season on yield parameters is shown in table 6.The two way analysis of variance revealed that the season had a significant effect $(p<0.05)$ on all the yield parameters excepted one fruit weight (table 6). Values recorded for the wet season were significantly higher than those observed in the dry season. Seed yield, noted for the wet season (1282.10 $\mathrm{kg}$ ha-1)was 13 times higher than that of the dry season (99.40 kg ha-1).

TABLE 6. Effect of the season on fruit weight per tree, one fruit weight, seed weight per tree and seed yield.

\begin{tabular}{|l|c|c|c|c|}
\hline \multirow{2}{*}{\multicolumn{1}{|c|}{ Parameters }} & \multicolumn{2}{c|}{ Seasons } & \multicolumn{2}{c|}{ Statistical parameters } \\
\cline { 2 - 5 } & Dry season & Wet season & F & P \\
\hline Fruit weight per tree (g) & $62.25 \mathrm{~b}$ & $788.43 \mathrm{a}$ & 71.02 & $<0.001$ \\
\hline One fruit weight (g) & $1.920 \mathrm{a}$ & $2.030 \mathrm{a}$ & 1.46 & 0.235 \\
\hline Seed weight per tree (g) & $39.78 \mathrm{~b}$ & $512.83 \mathrm{a}$ & 72.60 & $<0.001$ \\
\hline Seed yield (kg ha-1) & $99.40 \mathrm{~b}$ & $1282.10 \mathrm{a}$ & 72.60 & $<0.001$ \\
\hline
\end{tabular}

Means followed by the same letter within columns do not differ significantly at $\mathrm{P}<0.05$ by Tukey's test.

The influenceof the accession on yield components is summarized in table 7. There were significant differences between accessions for yield parameters, out of fruit weight. Fruit weight per tree ranged from $243.20 \mathrm{~g}$ (CE98) to $826.35 \mathrm{~g}$ (CE6) while seed weight per tree varied from154.38 $\mathrm{g}$ (CE98) to $547.90 \mathrm{~g}$ (CE6). Seed yield per hectare were between 385.90 (CE98) and 1369.80 (CE6). For all these parameters, the accession CE6 had the highest values, followed by CE97 and CE95.

TABLE 7. Effect of the accession on fruit weight per tree, onefruit weight, seed weight per tree and seed yield.

\begin{tabular}{|l|l|l|l|l|l|l|l|l|}
\hline \multirow{2}{*}{\multicolumn{1}{|c|}{ Variables }} & \multicolumn{9}{|c|}{ Accessions } & \multicolumn{2}{c|}{$\begin{array}{c}\text { Statistical } \\
\text { parameters }\end{array}$} \\
\cline { 2 - 10 } & CE50 & CE95 & CE6 & CE97 & CE98 & CE14 & F & P \\
\hline Fruit weight per tree $(\mathrm{g})$ & $272.40 \mathrm{~b}$ & $421.70 \mathrm{ab}$ & $826.35 \mathrm{a}$ & $455.12 \mathrm{ab}$ & $243.20 \mathrm{~b}$ & $333.25 \mathrm{~b}$ & 4.07 & 0.005 \\
\hline One fruit weight $(\mathrm{g})$ & $1.83 \mathrm{a}$ & $1.86 \mathrm{a}$ & $1.98 \mathrm{a}$ & $1.96 \mathrm{a}$ & $2.07 \mathrm{a}$ & $2.14 \mathrm{a}$ & 1.16 & 0.352 \\
\hline Seed weight per tree $(\mathrm{g})$ & $175.50 \mathrm{~b}$ & $265.30 \mathrm{ab}$ & $547.90 \mathrm{a}$ & $290.23 \mathrm{ab}$ & $154.38 \mathrm{~b}$ & $224.51 \mathrm{~b}$ & 4.40 & 0.003 \\
\hline Seed yield (kg ha-1) & $438.7 \mathrm{~b}$ & $663.30 \mathrm{ab}$ & $1369.80 \mathrm{a}$ & $725.60 \mathrm{ab}$ & $385.90 \mathrm{~b}$ & $561.30 \mathrm{~b}$ & 4.40 & 0.003 \\
\hline
\end{tabular}

Means followed by the same letter within columns do not differ significantly at $\mathrm{P}<0.05$ by Tukey's test. 
The effect of the interaction between accession and season on yield parameters is shown in table 8.Results indicated that except fruit weight, all yield parameters (fruit weight per tree, seed weight per tree, seed yield) was significantly affected by the interaction between the season and the accession $(p<0.05)$.

The highest fruit weight per tree was recorded in CE6 (1552.70g) and CE97 (893.50g) during the wet season. The lowest value of this parameter was observed in CE97 (16.70g) during the dry season. But there was no significant difference between that value and those of CE14, CE98, CE50, CE6 and CE95 during the dry season.

TABLE 8. Interaction effect of accession and season on fruit weight per tree, one fruit weight, seed weight per tree and seed yield.

\begin{tabular}{|l|l|l|l|l|l|}
\hline \multicolumn{2}{|c|}{ Variables } & \multicolumn{4}{c|}{ Yield parameters } \\
\hline Accession & Season & $\begin{array}{c}\text { Fruit weight } \\
\text { per tree (g) }\end{array}$ & $\begin{array}{c}\text { One fruit } \\
\text { weight (g) }\end{array}$ & $\begin{array}{c}\text { Seed weight } \\
\text { per tree (g) }\end{array}$ & $\begin{array}{c}\text { Seed yield } \\
\text { (kg ha-1) }\end{array}$ \\
\hline CE50 & Dry Season & $80.00 c$ & $1.69 a$ & $50.80 c$ & $127.00 c$ \\
\hline CE50 & Wet season & $464.80 b c$ & $1.96 a$ & $300.20 b c$ & $750.50 b c$ \\
\hline CE95 & Dry Season & $139.10 c$ & $1.86 a$ & $85.40 c$ & $213.40 c$ \\
\hline CE95 & Wet season & $704.30 b c$ & $1.85 a$ & $445.30 b c$ & $1113.10 b c$ \\
\hline CE6 & Dry Season & $100.00 c$ & $1.99 a$ & $65.70 c$ & $164.30 c$ \\
\hline CE6 & Wet season & $1552.70 a$ & $1.97 a$ & $1030.10 a$ & $2575.30 a$ \\
\hline CE97 & Dry Season & $16.70 c$ & $1.98 a$ & $11.40 c$ & $28.4 c$ \\
\hline CE97 & Wet season & $893.50 a b$ & $1.95 a$ & $569.10 a b$ & $1422.80 a b$ \\
\hline CE98 & Dry Season & $19.70 c$ & $2.01 a$ & $12.90 c$ & $32.30 c$ \\
\hline CE98 & Wet season & $466.80 b c$ & $2.14 a$ & $295.90 b c$ & $739.60 b c$ \\
\hline CE14 & Dry Season & $18.10 c$ & $1.96 a$ & $12.60 c$ & $31.40 c$ \\
\hline CE14 & Wet season & $648.50 b c$ & $2.31 a$ & $436.50 b c$ & $1091.20 b c$ \\
\hline F & & 3.50 & 0.51 & 3.78 & 3.78 \\
\hline P & & 0.012 & 0.769 & 0.008 & 0.008 \\
\hline
\end{tabular}

Means followed by the same letter within columns do not differ significantly at $\mathrm{P}<0.05$ by Tukey's test.

Seed weight per tree was significantly higher in CE6 (1030.10 g) and CE97 (569.10 g) during the wet season. It was significantly lower in CE97, CE14, CE98, CE50, CE6 and CE95 in the dry season. The trend is similar for seed yield. 


\section{Annual yield}

Cumulative values (from February to November 2012) of yield parameters are shown in table 9. Whatever the parameter considered, highest values were recorded in CE6, CE97 and CE95, while lowest value was observed in CE98.

TABLE 9. Cumulative values of yield parameters for 6 accessions of $J$. curcas.

\begin{tabular}{|l|l|l|l|}
\hline Accession & \multicolumn{1}{|c|}{$\begin{array}{c}\text { Fruit weight per tree } \\
(\mathbf{g})\end{array}$} & \multicolumn{1}{|c|}{$\begin{array}{c}\text { Seed weight per tree } \\
(\mathbf{g})\end{array}$} & \multicolumn{1}{|c|}{$\begin{array}{c}\text { Seed yield } \\
\text { (kg ha-1) }\end{array}$} \\
\hline CE50 & $544.50 \mathrm{~b}$ & $350.80 \mathrm{~b}$ & $877.30 \mathrm{~b}$ \\
\hline CE95 & $843.00 \mathrm{ab}$ & $530.00 \mathrm{ab}$ & $1326.30 \mathrm{ab}$ \\
\hline CE6 & $1652.30 \mathrm{a}$ & $1095.50 \mathrm{a}$ & $2739.30 \mathrm{a}$ \\
\hline CE97 & $910.00 \mathrm{ab}$ & $580.00 \mathrm{ab}$ & $1451.00 \mathrm{ab}$ \\
\hline CE98 & $486.00 \mathrm{~b}$ & $308.50 \mathrm{~b}$ & $771.50 \mathrm{~b}$ \\
\hline CE14 & $666.30 \mathrm{ab}$ & $448.50 \mathrm{~b}$ & $1122.50 \mathrm{~b}$ \\
\hline $\mathrm{F}$ & 3.81 & 3.96 & 4.27 \\
\hline $\mathrm{P}$ & 0.012 & 0.010 & 0.010 \\
\hline
\end{tabular}

Means followed by the same letter within columns do not differ significantly at $P<0.05$ by Tukey's test.

This study showed significant effect of the studied factors (season, accession) and interaction between them on floral traits of $\mathrm{J}$. curcas. The observations revealed that flowering of the six accessions studied was continuous with two peaks. The first peak occurred in hot dry season while the second, with the highest number of inflorescences, appeared early in the wet season. These results were reported in Asia (Sukarin et al., 1987; Kaur et al., 2011) and Florida (Nietzsche et al., 2014). Full bloom of J. curcas occurred between the beginning of April and the end July. Flowering parameters including the number of female flowers per inflorescence and male to female flower ratio change significantly with the season. Overall, wet season has significantly fostered female flowers development and induced low male to female ratio. Thus, the number of female flowers ranged of 2.47-11.87 in the wet season with an average of 7.13 . In the dry season, this parameter varied from 1.67 to 5.73 with an average of 4.56. This is consistent with observations reported for Florida (Nietzsche et al., 2014). The period of full bloom of the accessions and installation of the second flowering peak coincides with the warmer months with temperatures ranging between 27.5 (June) and 27.7 ${ }^{\circ} \mathrm{C}$ (July).Also, the wet season begins in the study region, between June and July. Therefore, the best performance of flowering in the starting of the wet season (higher peak and highest production of female flowers), established in this study, may be related to climatic conditions particularly the high temperatures and increase of soil moisture with installing of rainfall. These observations suggest that floral initiation and development of female flowers of $\mathrm{J}$. curcas requires high temperatures and moderate humidity. In a study conducted by Nietzsche et al. (2014) in Florida, it has been observed that $J$. curcas flowering begins with rising temperatures and precipitation.Wu et al. (2011) reported that female sites on inflorescences of $J$. curcas occur mostly in seasons with high temperature and rainfalls. They also observed that the right 
amount of rainfall may possibly enhance the number of female flowers for each inflorescence, while too much or too less would not favor the occurrence of female flowers.

However, we found in this study, that effect of season on the number of male flowers was not significant. This result suggests that the production of female flowers is more environmentally sensitive than the male flowers that would depend more on genetic factors. It is consistent with the observations of Anandalakshmi et al. (2015) that showed that female flower production is more sensitive than male flowers. In a study conducted in China to understand organization of the flower sexes in J. curcas, Wu et al. (2011) documented that, male and female flowers have similar tissues and organs before female primordia emergence. So, they proposed that there are factors that regulate sex differentiation in this plant, which may selectively affect the action of homeotic genes in one whorl, such as only restraining the initiation of a gynoecium meristem in male $J$. curcas flowers.

This study also showed that the flowering characteristics vary significantly among accessions. In wet season, CE6 had more male (191.60) and female (11.87) flowers per inflorescence with lowest male to female flower ratio (16.40). In contrast, CE50 with lowest number of male (107.47) and female (2.47) flowers per inflorescence had highest male to female ratio (43.00). In the dry season, the highest number of male (154.87), female (5.73) flowers per inflorescence and lowest male to female ratio (22.81) was observed on CE97. These results are within the range of values obtained by previous studies (Raju \& Ezradanam, 2002; Ghosh \& Singh, 2008; Rao et al., 2008; Wijaya et al., 2009; Alam et al., 2011; Kaur et al., 2011; Nietzsche et al., 2014; Mat et al., 2015), for the number of male flowers (25-215), the number of female flowers (0 to 16.6) flowers and male to female flower (7.14-55.4). Wu et al. (2011) explained the lowest number of female flowers on $\mathrm{J}$. curcas inflorescences by the fact that the female and male flowers have remarkable position location features. But, female flowers do not appear at the male sites, while male flowers may develop at the female sites.

The present study has shown significant effect of the studied factors (season, accession) and interaction between them on fruiting traits of $\mathrm{J}$. curcas. It showed that the fruiting rythm of $J$. curcas in semi-arid area in Senegal is continuous with a short period of full production (September - October). Considering the average length of fruit set to physiological maturity is 3 to 5 weeks (Silip et al., 2010), that indicates that the majority of fruits are from fecundation that took place during the first ten days of August.

Some accessions (CE14, CE97 and CE98) had no fruit set in dry season but their full production ranged from 94 to $97 \%$ of total production. In contrast CE6, CE50 and CE95 had fruit set in dry season and their full production varied from 66 to $87 \%$ of total fruit production. These results indicate that J.curcas harvest should be done in wet and dry season according to accessions. This would reduce the high labor costs of harvesting J. curcas fruit (Everson et al., 2013). This study also noted that the season has a significant influence on yield parameters. Overall, production of fruits and seeds was better in the wet season than in the dry season. Thus, seed weight per tree ranged from 11.40 to $85.40 \mathrm{~g}$ in dry season with an average of $39.78 \mathrm{~g}$; in wet season it was between 295.90 and $1030.10 \mathrm{~g}$ with an average of $512.83 \mathrm{~g}$. High fruit and seed production of accessions in the wet season are due to better high flowering with a greater number of female flowers (Ferry, 2006). In addition, the values of male to female 
flowers ratio observed show that there are enough male flowers to ensure good pollination. However, the low number of female flowers is a major constraint of production. Our results can be explained by the fact that in the wet season, the efficiency of flowering (number of fruits / number of female flowers per inflorescence) is higher and humidity conditions are more favorable to fruit growth. Ma et al. (2016) reported that J. curcas have high demand for water during flowering and fruiting period in the dry-hot valley of Chin-sha River China. Anandalakshmi et al. (2015) mentioned that the annual increase in fruiting success of a three year old plantation in Tamil Nadu, India, was due to sufficient rainfall accompanied by availability of nutrients. In South Florida, where summer season is characterized by high average precipitation $(1473 \mathrm{~mm} / \mathrm{yr})$ and high average temperatures $\left(29^{\circ} \mathrm{C}\right)$, Nietzsche et al. (2014) reported that fruit set average is highest in that season $(75.5 \%)$ compared to fall, indicating a positive effect of climate on this characteristic. Also, our results showed that there are significant differences among accessions for the cumulative yield (dry and wet seasons). In terms of yield, CE6 is the better accession with a cumulative seed yield of $1095.50 \mathrm{~g}$ per tree or $2739.3 \mathrm{~kg}$ ha-1. CE98 and CE50 with lowest number of flowers in wet season produced 308.50 and $350.80 \mathrm{~g}$ per tree as cumulative seed yield, respectively. Previous works (Rao et al., 2008; Wijaya et al., 2009; Wani et al., 2012; Diedhiou et al., 2012b; Shabanimofrad et al., 2013; Singh et al., 2013) in Asia and in South Africa (Everson et al., 2013) demonstrated that seed yield ranged from 32 to $745.72 \mathrm{~g}$ per tree for 5 -years field of $\mathrm{J}$. curcas. However, the maximum yield obtained in our study is higher than the maximum values found by these authors, due to differences between environmental conditions, tillage and plant material (Chang-Wei et al., 2007; Nietzsche et al., 2014).

In this study, the highly significant variability of floral and fruiting traits found among accessions, could be associated with the genetic differences between these accessions and the climate conditions, particularly temperature, since plants grown in relatively homogeneous soil conditions. Therefore, it is important to select high yielding accessions to improve the profitability of plantations. In this perspective, as suggested by Singh et al. (2010), the number of female flowers borne by the plant may be given more weightage rather than selecting plants with better male to female ratio and number of inflorescences borne by the plant. However, our results suggest that we can also improve the performance of plantations through water supply at the beginning of flowering and dry season.

This work demonstrated that flowering and fruiting of J.curcas were continuous during ten months, with periods of full bloom and full fruit production. The flowering cycles of different accessions showed one to two peaks, one in the dry season and another one early in the rainy season.

The characteristics of flowering and fruiting change significantly according to the accessions and the season. The wet season has been more favorable for the production of flowers. Also during this period, J. curcas had between 66 and $97 \%$ of total fruit production. Four accessions had highest seed yield ( $\geq 1 \mathrm{t}$ ha-1); and could be promising for the production of biofuel.

Based on our results, to better understand the reproductive biology and phenology of $J$. curcas, it is important to determine the role of climate and soil moisture in the flowering and fruiting of this species. 


\section{ACKNOWLEDGEMENTS}

The authors are grateful to African Union and to European Union for financial assistance to this study through "10th European Fund for Development" and African Union Research Grant (EU - financed grant contracts for external actions), grant contract $N^{\circ}$ AURG/094/2012 CRS $N^{\circ}$ 2012/289-014. The authors are thankful to Moussa NDIONE and Chérif CISSE for help in collection of $\mathrm{J}$. curcas seeds and management of the plantation.

\section{REFERENCES}

AHOTON, LE ; QUENUM, F (2012) Floral biology and hybridization potential of nine accessions of Physic nut (Jatropha curcas L.) originating from three continents. Tropicultura 30 (4): 193-198.

ALAM, N C N; ABDULLAH, T L; ABDULLAH, N A P (2011) Flowering and fruit set under Malaysian climate of Jatropha curcas L. American Journal of Agricultural and Biological Sciences 6(1): 142-147.

ANANDALAKSHMI; SIVAKUMAR, V; WARRIER, R R; NARMATHA BAI, V (2015) Dynamics of flowering and fruiting in Jatropha curcas L. and its implications. Electronic Journal of Plant Breeding 6(3): 813-825.

CHANG-WEI, L; KUN, L; YOU, C; YONG-YU, S (2007) Floral display and breeding system of Jatropha curcas L. Forestry Studies in China 9(2): 114-119.

DIÉDHIOU, I; DIÉDHIOU, P M; NDIR, K N; BAYALA, R; OUATTARA, B; MBAYE, B; KÂNE, M; DIA, D; WADE, I (2012) Diversity, farming systems, growth and productivity of Jatropha curcas L. SudanoSahelian Zone in Senegal, West Africa. In CARELS, N; SUJATHA, M; BAHADUR, B (eds) Jatropha, challenges for a new energy crop Springer Science + Business Media; New York, USA; pp 281-295.

EVERSON, C S; MENGISTU, M G; GUSH, M B (2013) A field assessment of the agronomic performance and water use of Jatropha curcas in South Africa. Biomass and Bioenergy 59: 59-69.

FAO (1998) World reference base for soil resources. Food and Agriculture Organization of the United Nations, Rome, Italy.

FERRY, Y (2006) Menghitung perkiraan produksi Jarak Pagar. Info Tek Jarak Pagar (Jatropha curcas L.), 1(2): $5-8$.

FRESNEDO-RAMIREZ, J (2013) The floral biology of Jatropha curcas L. - a review. Tropical Plant Biology 6 (1): 1-15. Doi: 10.1007/s12042-012-9113-x.

GHOSH, L; SINGH, L (2008) Phenological changes in Jatropha curcas in subhumid dry tropical environment. Journal of Basic and Applied Biology 2(1): 1-8.

HELLER, J (1996) Physic nut Jatropha curcas L. promoting the conservation and use of underutilized and neglected crops. International Plant Genetic Resources Institute, Rome, Italy.

KAUR, K; DHILLON, G P S; GILL, R I S (2011) Floral biology and breeding system of Jatropha curcas in North-Western India. Journal of Tropical Forest Science 23(1): 4-9.

KIZITO, F; DRAGILA, M I; SĖNE, M; LUFAFA, A; DICK, R P; DIEDHIOU, I; DOSSA, E; KHOUMA, M; NDIAYE, S; BADIANE, A (2006) Seasonal soil water variation and root patterns among two semi-arid shrubs coexisting with Pearl millet in Senegal, West Africa. Journal Arid Environments 67: 436-455.

MA, S ; ZHOU, L ; PU, G ; LEI, B ; HOU, L ; DAI, X; YU, T (2016) Effects of altitude and water on flowering and fruiting of Jatropha curcas L. Pak J Bot 47(2): 537-541.

MAT, N H C; BHUIYAN, M A R; SENAN, S; YAAKOB, Z; RATNAM, W (2015) Selection of high yielding Jatropha curcas L. accessions for elite hybrid seed production. Sains Malaysiana 44(11) : 1567-1572. 
NIETZSCHE, S ; VENDRAME, W A ; CRANE, J H; PEREIRA, M C T (2014) Assessment of reproductive characteristics of Jatropha curcas L. in south Florida. GCB Bioenergy 6: 351-359.

RAJU, A J S ; EZRADANAM, V (2002) Pollination ecology and fruiting behaviour in a monoecious species, Jatropha curcas L. (Euphorbiaceae). Current Science 83: 1395-1398.

RAO, G; KORWAR, G; SHANKER, A K; RAMAKRISHNA, Y (2008) Genetic associations, variability and diversity in seed characters, growth, reproductive phenology and yield in Jatropha curcas (L.) accessions. Trees 22: 697-709.

SHABANIMOFRADA, M; RAFIIA, M Y; MEGAT, W P E; BIABANIA, A R; LATIF, M A (2013) Phenotypic, genotypic and genetic divergence found in 48 newly collected Malaysian accessions of Jatropha curcas L. Industrial Crops and Products 42: 543-551.

SILIP, J J; TAMBUNAN, A H; HAMBALI, H; SUTRISNO, S; SURAHMAN, M (2011) Life cycle duration and maturity heterogeneity of Jatropha curcas L. Journal of Sustainable Development 3(2): 1-5.

SINGH, A S; PATEL, M P; PATEL, T K; DELVADIA, D R; PATEL, D R; KUMAR, N; NARAYNAN, S; FOUGAT, R S (2010) Floral biology and flowering phenology of Jatropha curcas. Journal of Forest Science 26 (2): 95-102.

SINGH, B; SINGH, K; RAO, G R; CHIKARA, J; KUMAR, D; MISHRA, D K; SAIKIA, S P; PATHRE, U V; RAGHUVANSHI, N; RAHI, T S; TULI, R (2013) Agro-technology of Jatropha curcas for diverse environmental conditions in India. Biomass and Bioenergy 48: 191-202.

SUKARIN, W; YAMADA, Y; SAKAGUCHI, S (1987) Characteristics of physic nut, Jatropha curcas L. a new biomass crop in the tropics. Japan Agricultural Research Quartely 20: 302-303.

TRAORÉ, M; NACRO, H B; DOAMBA, W F; TABO, R; NIKIEMA, A (2015) Effets de doses variées du tourteau de Jatropha curcas sur la productivité du mil (variété HKP) en condition pluviale en Afrique de l'Ouest. Tropicultura, 33(1): 19-25.

VIDAL, V A (1962) Oleaginosas do Ultramar Portugês. Mem. Junta Invest. Ultramar 31: 129-145.

WANI, T A; KITCHLU, S; RAM, G (2012) Genetic variability studies for morphological and qualitative attributes among Jatropha curcas $\mathrm{L}$. accessions grown under subtropical conditions of North India. South African Journal of Botany 79: 102-105.

WIJAYA, A; TIDIANA, S; HARUN, M U; HAWALID, H (2009) Flower characteristics and the yield of Jatropha (Jatropha curcas L.) accessions. HAYATI Journal of Biosciences, 16(4): 123-126.

WU, J ; LIU, Y ; TANG, L ; ZHANG, F ; CHEN, F (2011) A study on structural features in early flower development of Jatropha curcas L. and the classification of its inflorescences. African Journal of Agricultural Research 6(2): 275-284. 